\section{Por uma Igreja com rosto amazônico. Implicações e tarefas*}

\section{Agenor Brighenti ${ }^{\mathrm{a}}$}

Pontifícia Universidade Católica de Curitiba, Brasil https://orcid.org/0000-0002-9399-2621

RECEBIDO: 02-04-19. APROVADO: 04-06-19

Resumo: Uma Igreja com rosto amazônico é uma aspiração dos cristáos da floresta, ribeirinhos e das zonas urbanas, em uma regiāo portadora de desafios que transcendem as próprias fronteiras. Por isso, o Sínodo da Amazônia levanta questóes e acena tarefas para a Igreja como um todo. A pluriculturalidade e a pluri-religiosidade de seus povos desafia o cristianismo a expressar-se em uma eclesialidade pluriforme, respeitosa e acolhedora das diferenças. Isso só é possível com a configuração de igrejas autóctones, que tenham na inculturação da fé o referencial da evangelização. Por sua vez, igrejas culturalmente novas colocam o imperativo de uma consequente "conversão pastoral da Igreja" como um todo, incluídas suas estruturas.

Palavras-chave: Igreja; sínodo; Amazônia; inculturação; conversão pastoral.

\section{For a Church with an Amazonian Face. Implications and Tasks}

AвsTraCt: A Church with an Amazonian face is an aspiration of Christians who live in the Amazon region, whether they are the "ribeirinhos" and dwellers in urban areas. This is a region, which poses challenges that transcend its own borders. Therefore, the Amazon Synod raises questions and suggests tasks for the Church as a whole. The pluri-culturality and pluri-religiosity of the Amazon's peoples challenge Christianity to express itself in an ecclesiology characterized by plurality, respect, and acceptance of differences. This will only be possible with the configuration of indigenous churches, whose inculturation of faith has evangelization as its reference. At the same time, culturally new Churches impose the imperative of a "pastoral conversion of the Church" as a whole, including its structures.

Key Words: Church: Synod; Amazon Basin; Inculturation; Pastoral conversion.

\section{Cómo CITAR:}

Brighenti, Agenor. "Por uma Igreja com rosto amazônico. Implicaçôes e tarefas". Theologica Xaveriana (2020): 1-28. https:// doi.org/10.11144/javeriana.tx70.irait

*Artículo de reflexión

${ }^{a}$ Autor de correspondencia. Correio eletrônico: agenor.brighenti@pucpr.br 
Um rosto próprio para a Igreja na Amazônia é um grito dos cristãos da floresta, ribeirinhos e das zonas urbanas ${ }^{1}$ dirigido ao Sínodo dos Bispos para a Região Panamazônica². Teologicamente é um direito, pois a Igreja é essencialmente pluricultural e, pastoralmente, é um dever porquanto é condição para tornar presente o Reino de Deus em uma realidade particular, sob pena da fé não se encarnar em seu contexto.

Para isso, estão implicadas três questôes de fundo: a necessidade da configuração das igrejas locais como igrejas autóctones; a autonomia necessária para a inculturaçáo da fé e, assim, poder plasmar um rosto segundo o próprio contexto; e, tal como indicou Santo Domingo ${ }^{3}$ e Aparecida ${ }^{4}$ colocou em relevo, o imperativo de uma consequente "conversão pastoral da Igreja" como um todo, incluídas suas estruturas, neste caso, para responder aos desafios da ação evangelizadora na Amazônia.

Trata-se de questóes que transcendem a região amazônica, cujas respostas abrem caminho para a Igreja como um todo. Como a firma o Instrumentum laboris do Sínodo, é preciso "reconhecer a irrupção da Amazônia como um novo sujeito", ainda não levado em conta "suficientemente no contexto nacional e internacional, nem na vida da Igreja”. Enquanto "sujeito", a Amazônia constitui um "paradigma”, que quando assumido com todas as suas consequências leva, inevitavelmente, na evangelização a uma "amazonização da Igreja" e no cuidado com a ecologia a uma "amazonização do mundo"'.

A legitimidade de uma Igreja autóctone remete a uma eclesialidade pluriforme, resgatada pelo Concílio Vaticano II em sua "volta às fontes" ( $a d$ rimini fontes) ${ }^{7}$ bíblicas e patrísticas. Nos primórdios do movimento de Jesus, as "igrejas-filhas" iam nascendo de "igrejas-mãe", diferentes, mas sem se excomungarem. Encarnando o Reino de Deus, do qual elas são seu sacramento em seu contexto particular, as diferenças entre as igrejas, longe de ser um perigo à unidade, atestava o exercício de uma unidade de diversidades.

${ }^{1}$ Paloschi, “O Sínodo da Amazônia: grito à consciência, memória da missão, opção pela vida”, 17-19.

${ }^{2} \mathrm{O}$ documento preparatório da assembleia especial do Sínodo dos Bispos para a Regiáo Amazônica vai nesta perspectiva: "Amazonía: nuevos caminos para la Iglesia y para una ecología integral".

${ }^{3}$ Celam, Documento de Santo Domingo. Quarta Conferência Geral dos Bispos da América Latina e Caribe. Santo Domingo, 1992.

${ }^{4}$ Celam, Documento de Aparecida. Quinta Conferência Geral dos Bispos da América Latina e Caribe.

${ }^{5}$ Sínodo dos Bispos-Secretaria Geral, Amazônia: novos caminhos para a Igreja e para uma ecologia integral. Instrumentum laboris 2.

${ }^{6}$ Roca Alcazar, "El Sínodo amazónico, la Amazonía y la Iglesia”, 55-67.

${ }^{7}$ Expressão cunhada pela Igreja no século IX, inconformada pela reforma litúrgica levada a cabo pelo imperador, introduzindo elementos da cultura e da religião tradicional germânica, em dissonância com as fontes bíblicas e patrísticas. 
A Igreja é "Igreja de igrejas" locais", presididas pela Igreja de Roma. A catolicidade ou universalidade da Igreja está presente em cada Igreja local, pelo fato delas ter o mesmo em comum com as demais. No contexto atual, a configuração de igrejas autóctones exige uma "sã descentralizaçâo", sobretudo em relaçâo à Igreja de Roma, particularmente da cúria romana, tal como vem insistindo o papa Francisco.

Já uma Igreja autóctone, além de teologicamente remeter a uma eclesialidade pluriforme, pastoralmente nos expóe à necessidade da inculturação da fé, condição para plasmar um rosto próprio, a partir das características e necessidades de seu próprio contexto. Da mesma forma que "o Verbo ao encarna-se se fez cultura" ${ }^{10}$, a Igreja também é fator cultural. Em seu itinerário, por séculos, a adoção de uma eclesialidade pluriforme configurou uma Igreja pluricultural.

Entretanto, na medida em que a centralizaçáo foi transformando a unidade de diversidades reinante por séculos, em uniformidade a um centro autorreferencial a ser reproduzido nas periferias, uma Igreja marcadamente monocultural se impôs como modelo de Igreja universal. A renovação do Vaticano II, ao conceber a universalidade a partir das particularidades, fez da inculturação da fé um imperativo pastoral. Trata-se da encarnação da mensagem e da endoculturação dos mensageiros, da Igreja como um todo, incluídas suas estruturas, em um contexto particular.

Finalmente, no momento atual, uma Igreja autóctone e inculturada em seu contexto exige, como têm insistido Aparecida e o papa Francisco, uma conversão pastoral, que em Santo Domingo abarca quatro âmbitos: a autoconsciência da Igreja, suas açôes, as relaçóes de poder e autoridade, assim como suas estruturas ${ }^{11}$. Para isso, critério importante é buscar responder às necessidades da evangelização oriundas do próprio contexto. Não há fidelidade ao Evangelho, sem fidelidade à realidade, na qual se quer encarná-lo. E a Amazônia apresenta necessidades muito concretas e urgentes.

O que se busca, aqui, abordar três questóes de fundo - o que caracteriza teologicamente uma Igreja autóctone, com rosto próprio e, pastoralmente, uma conversão pastoral da Igreja como um todo, incluídas suas estruturas. Para isso, vamos nos respaldar em documentos do magistério da Igreja e na reflexão teológica recente, plasmada no contexto da renovaçáo do Vaticano II e da teologia latino-americana.

\footnotetext{
8 Tillard, Église d'églises. L'écclesiologie de communion.

9 Francisco, Exortação apostólica Evangelii gaudium 30.

${ }^{10}$ Bento XVI, "Discurso inaugural”.

${ }^{11}$ Celam, Documento de Santo Domingo. Quarta Conferência Geral dos Bispos da América Latina e Caribe. Santo Domingo, 199230.
} 


\section{A Igreja como Igreja de Igrejas autóctones}

Uma dos problemas de fundo, relativo à legitimidade da autonomia das igrejas locais entre si e em relação à Igreja de Roma, é uma determinada concepção de universalidade que volatiliza as particularidades. Com isso, se nega a autenticidade de uma eclesialidade pluriforme ou a legitimidade de uma Igreja universal conformada por igrejas locais e autóctones.

$\mathrm{Na}$ América Latina e o Caribe, a fé cristã chegou em um primeiro momento sob o regime do padroado, segundo o modelo de Igreja pré-tridentino da península ibérica. Mais tarde, com a independência das colônias, Roma assume a gestão da Igreja e implanta um catolicismo romanizado, alinhado à Contra-Reforma de Trento. Em ambos, trata-se de uma "Igreja-reflexo"12 do padrão religioso e cultural, primeiro dos colonizadores e, depois, da particularidade romana. Houve vozes e práticas, que denunciaram e buscaram superar a aliança entre colonização e evangelização, mas foram periféricas e colocadas sob suspeita.

Ao contrário do primeiro milênio, no qual predominou o modelo eclesiológico neotestamentário - a universalidade da Igreja presente em cada Igreja local em comunhão com as demais igrejas -, a eclesiologia do segundo milênio sacrificou o caráter "local" e "particular" da Igreja, em favor de uma eclesialidade abstrata, em torno ao papa. A universalidade da Igreja irá confundir-se com a particularidade romana, que se expande e se impóe sobre as demais particularidades. Sobretudo depois da reforma protestante, para a Igreja da Contra-Reforma, "católico" será sinônimo de romano.

\section{A Igreja Local como "porção" e não "parte" da Igreja}

Embora tardiamente, o Vaticano II resgatou a eclesiologia do primeiro milênio, afirmando que na Igreja local está presente a "Igreja toda", inteira, ainda que não seja "toda a Igreja", pois a Igreja é "Igreja de igrejas" ${ }^{13}$. Na eclesiologia pré-conciliar, existe uma suposta Igreja universal, que precede e acontece nas igrejas locais, da qual o papa é o representante e o garante. Já na eclesiologia conciliar, não há Igreja nem anterior e nem exterior às igrejas locais.

Tal como aparece nos escritos neotestamentários, as igrejas que vão nascendo, não se constituem em "igrejas de", materializando uma suposta Igreja universal que as precede, mas "igrejas em”, a mesma e única Igreja, que está toda (inteira) na Igreja local e que se configura não uma filial ou cópia da "Igreja-mãe" pela qual nasceu, mas

\footnotetext{
${ }^{12}$ Lima Vaz, "Igreja-reflexo vs Igreja-fonte”, 17-22.

${ }^{13}$ Tillard, Église d'Églises. L'écclesiologie de communion, 217-305.
} 
uma Igreja diferente, com rosto próprio, culturalmente nova, encarnando a universalidade em sua particularidade.

A Igreja local é "porção" do povo de Deus, não "parte"; a porção contém o todo, já a parte não. Nela está "a Igreja toda", pois cada uma delas é depositária da totalidade do mistério de salvação, mas não é a "toda a Igreja”, porquanto nenhuma delas esgota este mistério. Daí o imperativo da Igreja local não fechar-se sobre si mesma, mas de abrir-se às demais igrejas locais, constituindo uma "Igreja de igrejas" ${ }^{14}$.

Para o Vaticano II, a catolicidade não é uma uniformidade generalizada que se impóe sobre as particularidades, absorvendo-as ou aniquilando-as. A universalidade da Igreja se deve não a uma única forma de ser Igreja, mas à mesma fé, à sua fonte trinitária e ao dom da salvação que Deus oferece a todo o gênero humano, fatores todos presentes em cada Igreja local. Segundo os Atos dos Apóstolos, a unidade consiste em "ter o mesmo" em comum (At 2,42ss.), ainda que de forma diferente, segundo a diversidade dos contextos. Nesta perspectiva, a Igreja, quanto mais encarnada em cada cultura, tanto mais é universal e católica ela é; e, inversamente, quanto mais encarnada em uma única cultura e presente deste modo nas demais culturas, tanto menos católica e universal ela se torna ${ }^{15}$.

\section{A necessária autonomia para uma Igreja autóctone}

Em Medellín"16, a Igreja na América Latina, com sua "recepção criativa" do Vaticano II, deixou de ser uma "Igreja-reflexo" ou caixa de ressonância de uma suposta "Igreja universal", para constituir-se numa fonte inspiradora e programática para as igrejas locais no subcontinente ${ }^{17}$. A realizaçáo de cinco conferências gerais é a atestação do esforço de afirmação de sua autonomia e determinação na busca da efetivação de igrejas autóctones. $\mathrm{O}$ mesmo se pode dizer com relação às conferências episcopais nacionais, em especial de seu importante papel desempenhado no processo de recepção do Concílio Vaticano II nas igrejas locais.

Entretanto, o processo de construção de igrejas autóctones a partir de Medellín, logo seria obstaculizado por segmentos eclesiais atrelados à eclesiologia pré-conciliar, tanto internos como externos à Igreja na América Latina. Com o final do pontificado

\footnotetext{
${ }^{14}$ Legrand, "La réalisation de l'Église en un lieu", 145ss.

${ }^{15}$ Amerindia, Hacia el Sinodo Panamazónico. Desafios y aportes desde América Latina y el Caribe, 77-82.

${ }^{16}$ Celam, Documento de Medellín. Segunda Conferência Geral dos Bispos da América Latina e Caribe.

${ }^{17}$ Sobre esta mudança radical, ver: Scatena, In populo pauperum. La chiesa latinoamericana dal Concilio a Medellin (1962-1968). Sobre a recepção do Vaticano II na América Latina, ver: Sobrino, "El Vaticano II y la Iglesia latinoamericana", 105-134; Gutiérrez. "La recepción del Vaticano II en América Latina”, 213-237.
} 
de Paulo VI (1978) e a eleição de João Paulo II, teve início um processo de "involução eclesial" ${ }^{18}$ em relação à renovação do Vaticano II $^{19}$, que se prolongou até à renúncia de Bento XVI e a eleição do papa Francisco ${ }^{20}$.

$\mathrm{Na}$ tessitura da tradição libertadora da Igreja na América Latina, a Conferência de Puebla (1979) já seria um freio à "recepção criativa" do Vaticano II feita por Medellín ${ }^{21}$ e, Santo Domingo, praticamente seu estancamento ${ }^{22}$. Pouco a pouco, voltou-se novamente ao histórico centralismo da cúria romana, que exerceria ferrenho controle, sobretudo sobre as conferências episcopais, que tiveram seu estatuto teológico questionado e sua configuração jurídica readequada a características do modelo eclesial pré-conciliar ${ }^{23}$.

O controle se estreitou também sobre as igrejas locais, em particular pela nomeação de um novo perfil de bispo, mais zeloso pela ortodoxia e menos pastor que administrador ${ }^{24}$. Neste contexto, Aparecida e a eleição do papa Francisco foram uma grata surpresa, pois reafirmaram a renovação do Vaticano II e resgataram Medellín²5, ainda que a reversão do processo de involuçáo eclesial encontre forte oposição por parte de segmentos eclesiais, nostálgicos da Igreja da neocristandade.

O projeto de reforma da cúria romana, levado a cabo pelo papa Francisco desde a primeira-hora de seu pontificado, sinaliza para uma "sã descentralizaçáo" do primado e uma maior autonomia das conferências episcopais e das igrejas locais. O objetivo de fundo é resgatar o exercício da sinodalidade entre as igrejas e no interior delas. Para a configuração de igrejas autóctones no subcontinente, é fundamental que as conferências episcopais, sejam elas continentais ou nacionais, tenham um papel

\footnotetext{
${ }^{18}$ González Faus, "El meollo de la involución eclesial”, 67-84.

${ }^{19}$ Ver Ladrière e Luneau, Le retour des certitudes, e, também Luneau e Ladrière, Le rêve de Compostelle.

${ }^{20}$ Huenermann, "Silêncio frente ao Concílio Vaticano II?", 284. Para uma hermenêutica do Concílio Vaticano II, ver: Alberigo, "O Vaticano II e sua história”, 07-19; Melloni, "O que foi o Vaticano II? Breve guia para os juízos sobre o Concílio", 34-59; Theobald, "As opçóes teológicas do concílio Vaticano II: em busca de um princípio 'interno' de interpretação", 115-138.
}

${ }^{21}$ Keller, "A Conferência de Puebla: contexto, preparação, realização, conclusões, recepção", 83-93.

${ }^{22}$ A Conferência de Santo Domingo, realizada em condições adversas, praticamente não foi recebida pela Igreja no continente.

${ }^{23}$ Ratzinger e Messori, Informe sobre la fe, 68.

${ }^{24}$ Sobre a questáo, ver: Mardones, Postmodernidad y neoconservadorismo. Reflexiones sobre la fe y la cultura; Ladrière e Luneau, Le retour des certitudes; e, também, dos mesmos autores, Le rêve de Compostelle; González Faus, "El meollo de la involución eclesial", 67-84; Cartaxo Rolim, "Neoconservadorismo eclesiástico e uma estratégia política”, 259-281; Libânio, $A$ volta à grande disciplina.

${ }^{25}$ Codina, "A eclesiologia de Aparecida", 138-145. 
magisterial reconhecido e maior autonomia em relação à cúria romana, também em matéria disciplinar ou jurídica. Algo já foi feito no atual pontificado.

Prática efetiva do exercício da sinodalidade entre igrejas locais seria a realização de um Sínodo das Igrejas Locais da Amazônia na Amazônia, integrados por todos os segmentos da Igreja na regiāo ou mesmo um Concílio Plenário Panamazônico. Além disso, a consolidação de uma Igreja autóctone na Amazônia acena, também, para a criaçáo de um organismo colegial dos bispos da regiáo, que assegure organicidade e efetividade na ação evangelizadora em seu contexto ${ }^{26}$. Em consequência, o que é uma necessidade para a regiáo amazônica, a configuração de igrejas autóctones em outras regióes e continentes exigirá algo similar.

\section{Igreja com rosto amazônico: inculturação na interculturalidade}

Não há como desembarcar na Amazônia, sem deixar-se surpreender pelos ecos deste mundo, mais paraíso do que "inferno verde", ainda que ostensivamente marcado pelo pecado da cobiça, respaldado em uma economia de rapinagem, que ameaça a vida dos povos da floresta, a biodiversidade, os ecossistemas ${ }^{27}$. Os gritos que outrora ecoavam na floresta, ordinariamente de festa e alegria, hoje são de apreensão e dor, pelo avanço das queimadas e da pecuária, da soja e da cana, das mineradoras e dos grileiros.

A cobiça mercantilista e suicida chegou ao sacrilégio de dizimar povos inteiros e de silenciar vozes proféticas, no Brasil, como as de Chico Mendes, Pe. Ezequiel Ramin, Pe. Josimo, Ir. Dorothy, entre tantos outros. Infelizmente, a Igreja e o modo como se evangelizou nestas terras ${ }^{28}$, tem também sua parcela de responsabilidade em práticas de um passado ainda não superado.

\footnotetext{
${ }^{26}$ Sínodo dos Bispos-Secretaria Geral, Amazônia: novos caminhos para a Igreja e para uma ecologia integral.Instrumentum laboris $128 \mathrm{f}$.

${ }^{27}$ Sínodo de los Obispos- Secretaría, "Amazonía: nuevos caminos para la Iglesia y para una ecología integral. Lineamentos", 3.

${ }^{28}$ Uma boa aproximação ao conceito de "evangelização' se pode encontrar em: Ramos, Teología pastoral, 211-220; Esquerda Bifet, Teología de la evangelización. Curso de misionología, 27-43; Floristán, "Evangelización", 550-559.
} 


\section{Evangelização e colonização}

Ressalta o Instrumentum laboris (IL) que a Amazônia é um mundo pluricultural, pluriétnico e plurirreligioso ${ }^{29}$ e que a evangelização implica um diálogo entre espiritualidades, credos e religióes amazônicas ${ }^{30}$. Entretanto, nem sempre se pensou e se agiu assim.

Durante o período da cristandade, o cristianismo se manteve como uma experiência de fé marcadamente monocultural, estruturado a partir da matriz católico-romana. Ainda no século XVI, com a conquista do novo mundo, as missóes continuarão desconhecendo as diferenças culturais e confundindo evangelização com a implantação da Igreja configurada nos moldes da cultura ocidental ${ }^{31}$. Em lugar de se encarnar a fé na cultura, o missionário implanta uma versão de cristianismo, plasmada segundo os parâmetros de sua própria cultura.

Uma Igreja com rosto próprio é uma Igreja encarnada em seu contexto concreto, fruto de um processo de proposição e acolhimento da fé, no seio do qual o sujeito é quem recebe o Evangelho e não quem o leva. Entretanto, em nossas terras, incluída Amazônia, o cristianismo foi implantado mais pela força do que pela persuasão. Os conquistadores que aqui desembarcaram se acreditavam investidos de uma missão, que consistia na "expansão do império e da fé". O cristianismo que chega ao continente é uma mescla de mercado e salvaçấo. Mundos completamente diferentes começam a tecer laços de interação e intercâmbio, mas também de subordinação política, exploração econômica e de dominação religiosa e cultural ${ }^{32}$.

Os aborígines, habitando em grandes contingentes cidades, muitas delas mais populosas que as maiores cidades da península ibérica ou da Europa, se expressavam em milhares de idiomas, grande parte deles hoje desaparecidos, e haviam tecido secularmente suas próprias culturas, seus mitos e religiōes. Entretanto, esses mesmos aborígines, construtores de grandes civilizaçóes como as civilizaçóes maia, asteca, inca e a guarani, entre tantas outras, tiveram que passar pela humilhante prova de averiguaçáo se eram civilizados ou mesmo se eram seres humanos. Argumentos estes, que justificaram sua escravidão, de boa-fé ou vil pretexto.

\footnotetext{
${ }^{29}$ Sínodo dos Bispos-Secretaria Geral, Amazônia: novos caminhos para a Igreja e para uma ecologia integral. Instrumentum laboris 36.

${ }^{30}$ Ibid. 39.

${ }^{31}$ Brighenti. Por uma evangelização inculturada. Princípios pedagógicos e passos metodológicos, 10-23. Ver, também, De França Miranda, Inculturaçâo da fé. Uma abordagem teológica, 15-33.

${ }^{32}$ Paloschi, "O Sínodo da Amazônia: grito à consciência, memória da missão, opção pela vida”, 19-23.
} 
$\mathrm{Na}$ região amazônica, a lógica colonialista reinante, sobretudo no período colonial, e que se prolonga até hoje em posturas neocoloniais tanto no âmbito sóciopolítico-econômico como religioso e eclesial, foi a responsável não só da subjugação dos povos originários, como do desaparecimento por completo de muitos deles ou de seu "isolamento voluntário" como estratégia de sobrevivência. Ao contrário de outras regióes em que missionários ou antropólogos pelo menos registraram a história de povos hoje dizimados, na Amazônia, a colonização não deixou nem vestígios de povos que milenarmente teceram suas culturas, religiôes, universo simbólico e línguas.

Neste mesmo contexto e paradigma missionário, aqui aportaram os negros, arrancados de suas terras, famílias, culturas e religióes em solo africano e feitos escravos no novo mundo. Estes estiveram submetidos a quatro séculos de escravidão, situação que as leis abolicionistas repararam na teoria, mas foram ineficazes na prática, razão pela qual os negros, ainda hoje, figuram entre os mais pobres entre os pobres ${ }^{33}$. Dados oficiosos dáo conta que, aproximadamente, onze milhóes e meio de escravos foram distribuídos entre as Américas do Norte, Central, Caraíbas e América do Sul, metade deles destinados ao Brasil. Remanescentes desta epopeia são os quilombolas, presentes também na região amazônica.

A independência das colônias não significou, entretanto, o fim da dominação. Terminada a colonizaçáo, veio o neocolonialismo, que com outros mecanismos continuou o doloroso processo de exclusão ${ }^{34}$. Com relação à Igreja, seria preciso esperar pela renovação do Vaticano II para mudar o paradigma da missáo. Para o Concílio, evangelizar não é implantar a Igreja, mas encarnar o Evangelho na vida de pessoas circunscritas a um contexto cultural particular. Na medida em que a Igreja toda, a Igreja Católica, está presente em cada Igreja local, é na particularidade que a universalidade se faz presente. E como a Igreja é uma "Igreja de igrejas" locais, a universalidade das particularidades leva, necessariamente, a um cristianismo pluricultural.

Segundo o Concílio, para encarnar o Evangelho no contexto de uma Igreja Local, não se trata de suprimir sua cultura, ao contrário, é preciso "conhecê-la, restaurála, conservá-la e desenvolvê-la segundo as novas condições e, finalmente, aperfeiçoá-la em Cristo, para que a fé e a nova Igreja não sejam estranhas na sociedade em que se inserem, mas que comece a penetrá-la e a transformá-la" ${ }^{35}$.

${ }^{33}$ Aparecido da Silva, "Théologie afro-américaine au Brésil: expression du pluralisme théologique", 183-197.

${ }^{34}$ Ver Brighenti, Divida externa e neocolonialismo. Por uma globalização da solidariedade. Aí se detalham os mecanismos atuais, que perpetuam a ótica colonizadora do passado.

${ }^{35}$ Concílio Vaticano II, “Decreto Ad gentes sobre a atividade missionária da Igreja (1965)” 21. 
Em consequência, a evangelização de um povo não consiste em incorporá-lo à Igreja, mas em levar a Igreja a se encarnar em sua vida. Com isso, a Igreja que nasce é sempre culturalmente nova e, por ser católica, isto é, por encarnar a universalidade na particularidade, é sempre pluricultural. Entre "incorporar" as pessoas à Igreja e "encarnar" a Igreja nas culturas, há uma diferença de paradigma, com implicaçôes pastorais concretas.

\section{A evangelização como relação dialógica e respeitosa do outro}

No caso da América Latina e do Caribe, a evangelizaçáo esteve atrelada ao modo como o Ocidente cristão tratou, durante cinco séculos, a questão do "outro" ${ }_{36}$, o diferente. A ótica, hora de "submissão" hora de "rejeiçáo" ou de "aniquilamento" do outro, caracteriza a lógica de violência com que esteve marcada a evangelização no subcontinente, em cujas causas está também uma miopia cultural, crendo-se portador de uma cultura superior ${ }^{37}$.

Pastoral e teologicamente, o horizonte aberto pelo Concílio Vaticano II permitiu romper com o eclesiocentrismo dos períodos de cristandade e neocristandade, marcado por uma missão centrípeta, que consistia em sair para fora da Igreja, a fim de trazer adeptos para dentro dela. Na ótica da Evangelii nuntiandi, que recolhe a contribuição dos processos pastorais e da reflexão teológica levada a cabo na América Latina, se passou a compreender a evangelização não mais como implantação da Igreja, mas como a encarnação do Evangelho, através de uma relação dialógica e horizontal, no encontro entre culturas, numa relação intercultural ${ }^{38}$.

A versão de cristianismo do missionário, sempre condicionada pela própria cultura, não é nem modelo e nem ponto de partida para a missão evangelizadora. Se o ponto de partida do processo de evangelização não for o outro e sua cultura, a missão continuará atrelada, consciente ou inconscientemente, a modelos colonizadores, numa dinâmica diametricamente oposta à do Evangelho. "Descolonizar as mentes"

\footnotetext{
${ }^{36}$ Ricoeur, Soi-même comme un autre, 409. Perspectiva posta em relevo por: Lévinas, Ethique et infn; Lévinas, Totalidad e Infinito.

${ }^{37}$ Beozzo, "Globalisation en Amérique latine dans le contexte historique des interactions mondiales", 86-87.

${ }^{38}$ Para uma abordagem das implicaçóes entre evangelização e culturas, ver: Comblin, "Inculturação e libertação", 423-432; Comblin, "Aporias da inculturação (1)", 664-684; Comblin, "Aporias da inculturação (2)", 903-929; Suess, "Inculturação: desafios, caminhos, metas", 81-126; Suess, "No Verbo que se fez carne, o Evangelho se faz cultura", 36-49; Suess, Evangelizar a partir dos projetos históricos dos outros. Ensaio de missiologia; Suess (org.), Culturas e evangelização. A unidade da razão evangélica na multiplicidade de suas vozes: pressupostos, desafios e compromissos.
} 
foi um forte apelo de Aparecida. Por sua vez, na proposta de uma "Igreja em saída", o papa Francisco fala da urgência de ir para as periferias, mas com o cuidado de não "domesticar as fronteiras".

Ao contrário do paradigma de uma missáo colonizadora, que parte da Igreja e do evangelizador, uma evangelização inculturada parte dos povos e suas culturas. Em primeiro lugar, distanciando-se da referida miopia etnocêntrica de um agente exógeno, parte do pressuposto que o sujeito no processo de evangelização não é quem leva o Evangelho, que deve apenas desempenhar o papel de mediador entre Evangelho e cultura, mas aqueles que o recebem, dado que o mesmo é sempre "recebido segundo o modo do receptor" ${ }^{39}$. Consequentemente, é mais adequado falar de comunidades eclesiais inculturadoras do Evangelho, uma vez que são elas mesmas os sujeitos do processo de inculturação, do que de comunidades eclesiais inculturadas.

Assim, dado que o Evangelho sempre se encontra sempre encarnado em culturas concretas, o processo de evangelização inculturada se dá essencialmente no encontro de culturas, num diálogo intercultural, cujo sujeito neste processo de assimilação da mensagem, são os que se quer evangelizar. Trata-se de um encontro de culturas mediado pelo Evangelho, mais precisamente entre quem leva a mensagem desde sua própria cultura e os que a recebem no seio de outra cultura. Nesta interação, se dá a explicitação da identidade das culturas em questão, a captação da respectiva alteridade em suas peculiaridades e diversidades, a afinidade de ambas as partes com os valores evangélicos, como também o discernimento dos limites, contradiçóes e desvios de cada cultura frente à mensagem veiculada.

Em consequência, entre quem leva e quem recebe a mensagem se estabelece, de alguma forma, um processo de evangelizaçáo mútua, na medida em que, por um lado, o receptor da mensagem revelada é convidado a deixar-se impregnar por ela e também o evangelizador, ao confrontar sua própria cultura com a cultura de seu interlocutor, revista agora desde a fé anunciada, a redescobre como portadora do Evangelho, porém, não como forma exclusiva ou privilegiada de propô-lo e vivê-lo.

Um verdadeiro processo de evangelizaçáo inculturada, por um lado, leva os evangelizadores a relativizar sua versão de cristianismo em relação ao Evangelho e, por outro, a igualmente identificar o que há de evangélico e anti-evangélico na cultura dos que estão acolhendo a mensagem cristã. É por isso que a evangelização será sempre, real ou potencialmente, crítica da cultura e, muitas vezes, um processo contra-cultural, ou seja, de denúncia profética, dos dois lados, tanto do lado de quem leva o Evangelho como de quem o recebe.

${ }^{39}$ De Aquino, Suma teológica I, q. 75, a. 5. 


\section{O rosto da Igreja na América Latina e um rosto de Igreja para a Amazônia}

Nos últimos tempos, graças à renovação do Vaticano II e sua "recepção criativa" levada a cabo pela Igreja na América Latina e no Caribe, tornamo-nos mais conscientes da necessidade de romper com essa lógica de violência presente tanto nos processos pastorais como na reflexão teológica.

Esforços sinceros na tessitura de um rosto próprio e tentativas de superação da lógica colonialista têm marcado esta nova trajetória, tal como atestam: as comunidades eclesiais de base, que esboçaram um rosto autóctone de Igreja; a leitura popular da Bíblia, que faz de quem recebe a mensagem o sujeito de sua interpretação e encarnação da mensagem em seu próprio; uma Igreja pobre e dos pobres, condição para uma Igreja de todos e testemunha do Evangelho; a inserção profética e transformadora dos cristáos na sociedade autônoma e pluralista, como forma de tornar presente o Reino de Deus na concretude da história; enfim, a teologia latino-americana, uma reflexão da práxis da fé em perspectiva libertadora, na pluralidade dos sujeitos e de seus contextos de exclusão - os pobres em geral e, em particular, os indígenas, os negros e as mulheres ${ }^{40}$.

Entretanto, não podemos desconhecer os retrocessos ocorridos nas últimas duas décadas de "involução eclesial" em relação à renovação conciliar e a tradição libertadora inaugurada por Medellín, com consequências para uma Igreja com rosto próprio. O medo de avançar e a busca de segurança num mundo instável e em profundas transformaçóes levaram segmentos importantes da Igreja a apostar em tradicionalismos massificadores das diferenças, assim como em configuraçôes da Igreja segundo os moldes da neocristandade ${ }^{41}$.

Ultimamente, a Conferência de Aparecida e, sobretudo, o pontificado novo de Francisco têm sido um novo alento para os segmentos da Igreja empenhados em levar a cabo uma ação evangelizadora e uma reflexão teológica, que tenha como ponto de partida o "outro", como alteridade gratuita, em sua particularidade, autonomia e contexto. Aparecida fala da necessidade de "descolonizar as mentes", de superar a mentalidade colonial e patriarcal ${ }^{42}$.

\footnotetext{
${ }^{40}$ Ver: Brighenti, "Énfasis pastorales de la Iglesia en América Latina y El Caribe en los últimos 50 años”, 375-398. Para uma visão da renovação conciliar na Igreja latino-americana, ver: Keller, "El proceso evangelizador de la Iglesia en América Latina. De Río a Santo Domingo", 5-43; Cadavid, "El camino pastoral de la Iglesia en América Latina y el Caribe", 331-374.

${ }^{41}$ Para uma visão mais completa, ver: Brighenti, "A pastoral na vida da Igreja. Repensando a missão evangelizadora em tempos de mudança”, 117-138.

${ }^{42}$ Celam, Documento de Aparecida. Quinta Conferência Geral dos Bispos da América Latina e Caribe 96.
} 
Uma Igreja encarnada na Amazônia implica em fazer ou continuar fazendo, entre outros: chegar a Palavra de Deus na língua de seus povos e situá-la no seio de pequenas comunidades de cunho doméstico; introduzir símbolos das culturas nativas compatíveis com o Evangelho na celebração dos ritos cristáos; acolher as expressóes musicais locais no canto litúrgico; multiplicar o número dos celebradores da Palavra, dos catequistas e demais ministérios ${ }^{43}$, nas comunidades eclesiais, em especial naquelas que não têm a celebração dominical da eucaristia; intensificar as ações pastorais de promoção humana como expressão de uma evangelização integral; etc.

Outras frentes, entretanto, precisam ser abertas como: acolher e apoiar a teologia índia, afro-americana, feminista e a ecoteologia, enquanto suporte na configuração de uma Igreja com rosto próprio ${ }^{44}$; criar novos ministérios, em especial para leigos e leigas, sobretudo para fora da Igreja, na defesa e promoção da vida, e de uma ecologia integral; formar um clero próprio, com rosto amazônico ${ }^{45}$, segundo o perfil das culturas locais ${ }^{46}$; superar estruturas e modos de organização da Igreja que não convergem com a sinodalidade eclesial, como o clericalismo, o paroquialismo, o universalismo de movimentos eclesiais e o isolamento de certas igrejas locais; assegurar a celebração da eucaristia dominical nas comunidades eclesiais ${ }^{47}$, pela ordenação de presbíteros casados $^{48}$; discernir a oportunidade de ordenação de mulheres ao diaconato, assim como a criação de outros ministérios próprios, segundo as necessidades da Igreja Local ${ }^{49}$, etc.

${ }^{43}$ Sínodo de los Obispos-Secretaría, "Amazonía: nuevos caminos para la Iglesia y para una ecología integral", 12.

${ }^{44}$ Ibíd., 11. Por primeira vez um documento do magistério, seja do magistério pontifício, seja do magistério latino-americano, o Instrumentum laboris $(I L)$ do Sínodo da Amazônia reconhece e recomenda a teologia latino-americana, ao mesmo tempo em que se refere à legitimidade da teologia índia (Sínodo dos Bispos-Secretaria Geral, Amazônia: novos caminhos para a Igreja e para uma ecologia integral. Instrumentum laboris 113).

${ }^{45}$ Ferreira, "Uma Igreja com rosto amazônico", 24. O Instrumentum laboris do Sínodo da Amazônia fala da necessidade da formação de um clero autóctone, o que implica, a partir da cosmovisão dos povos originários flexibilizar a disciplina do celibato, estanho à sua cultura e experiência religiosa (IL 12).

${ }^{46}$ Paloschi, "O Sínodo da Amazônia: grito à consciência, memória da missão, opção pela vida”, 21.

${ }^{47}$ Sínodo de los Obispos-Secretaría, "Amazonía: nuevos caminhos para la Iglesia y para uma ecologia integral", 9.

${ }^{48}$ Ferreira, "Uma Igreja com rosto amazônico", 28-29; ver: Lobinger, Padres para amanhã: proposta para comunidades sem eucaristia.

${ }^{49}$ Sínodo de los Obispos-Secretaría, "Amazonía: nuevos caminhos para la Iglesia y para uma ecologia integral", 13. Instrumentum laboris do Sínodo da Amazônia não entra na questão da ordenação de mulheres, ainda que se esteja fazendo uma pesquisa histórica oficial sobre a existência do diaconato feminino na tradição da Igreja. Para muitos bispos da Amazônia, dado que as comunidades eclesiais na regiẫo, hoje, são majoritariamente coordenadas por mulheres, a ordenação ao diaconato e ao presbiterato é uma necessidade premente e culturalmente madura. 
Dado que não existe cultura sem religião, a inculturação da fé no seio de um povo determinado não pode ignorar e muito menos menosprezar a religião dos interlocutores ${ }^{50}$. Um processo de inculturação enquanto encarnação da fé não faz da religião do outro tábula-rasa, mas se enxerta também na religião do outro, assumindo dela tudo o que é compatível com a mensagem cristã. E como o que não é compatível deve ser respeitado é parte integrante da inculturação não só o diálogo inter-cultural como também o diálogo inter-religioso ${ }^{51}$. A teologia índia é expressão deste diálogo ${ }^{52}$, pois não uma teologia sobre a cultura e a região de povos originários, mas uma interlocução entre fé cristã e religóes indígenas, feita por indígenas cristãos ${ }^{33}$.

\section{Conversão pastoral para superar} uma Igreja auto-referencial

Superando posturas de um longo período de involução eclesial, a Conferência de Aparecida e, em torno a ela, a exortaçáo Evangelii gaudium do papa Francisco, resgatam a renovação do Concílio Vaticano II e a tradição libertadora latino-americana, tecida em torno à Conferência de Medellín. Aparecida propóe uma conversão pastoral para um novo modelo de Igreja ${ }^{54}$, denominada pelo papa Francisco de "pastoral de conversão missionária”, que rompa com uma Igreja "auto-referencial” e a situe nas "periferias existenciais".

Para isso, a "conversáo pastoral", conforme proposta Santo Domingo ${ }^{55}$ e operacionalizada por Aparecida, precisa abarcar quatro âmbitos: a consciência da comunidade eclesial, a práxis ou as açóes pastorais, as relaçôes de igualdade e autoridade e as estruturas da Igreja.

\section{A conversão na consciência da comunidade eclesial}

Para Aparecida, em sintonia com Medellín e Santo Domingo, urge uma conversão pastoral da Igreja, por duas razóes básicas: a necessidade de se levar adiante a renovação

\footnotetext{
${ }^{50}$ Wolff, “A exigência do diálogo inter-religioso no Sínodo para a Amazônia 2019”, 69-93.

${ }^{51}$ Sínodo dos Bispos-Secretaria Geral, Amazônia: novos caminhos para a Igreja e para uma ecologia integral. Instrumentum laboris 136; Amerindia, Hacia el Sinodo Panamazónico. Desafios y aportes desde América Latina y el Caribe, 5 I- 53 .

${ }^{52}$ Sínodo dos Bispos-Secretaria Geral, Amazônia: novos caminhos para a Igreja e para uma ecologia integral. Instrumentum laboris 113.

53 López, "La teología índia en la globalización actual”, 109-130.

${ }^{54}$ Espeja Pardo. "La conversión pastoral como cambio de paradigmas, métodos y lenguajes", 299.

${ }^{55}$ Celam, Documento de Santo Domingo. Quarta Conferência Geral dos Bispos da América Latina e Caribe. Santo Domingo, 1992, 30.
} 
do Vaticano II e de, à luz do Concílio, dar novas respostas às novas perguntas, que os novos tempos apresentam, através de uma pastoral "decididamente missionária". Em Aparecida, há a consciência de que o Vaticano II, em sua volta às fontes bíblicas e patrísticas, é um divisor-de-águas no itinerário da Igreja, Por isso, constata Aparecida:

...tem nos faltado coragem, persistência e docilidade à graça para levar adiante a renovaçáo iniciada pelo Concílio Vaticano II e impulsionada pelas anteriores Conferências Gerais, para assegurar o rosto latino-americano e caribenho de nossa Igreja. ${ }^{56}$

Prova disso, dizem os bispos, são "algumas tentativas de voltar a uma eclesiologia e espiritualidade anteriores à renovaçáo do Vaticano II"s7.

Como modelo ultrapassado, tanto de Igreja como de pastoral, Aparecida cita a "pastoral de conservação"58 assim denominada por Medellín" período de cristandade e ainda vigente na Igreja, apesar de haver sido radicalmente superado pelo Concílio Vaticano II. Funciona centralizado no padre e na paróquia. A volta do clericalismo na atualidade é uma apologia deste modelo, que se reproduz também por meio de leigos clericalizados.

Em sua configuração pré-tridentina, a prática da fé é de cunho devocional, centrada no culto aos santos e composta de procissóes, romarias, novenas, milagres e promessas, práticas típicas do catolicismo popular medieval (um catolicismo "de muita reza e pouca missa, muito santo e pouco padre" 60 .

Já em sua configuração tridentina, a vivência cristã gira em torno do padre, baseada na recepção dos sacramentos e na observância dos mandamentos da Igreja. Neste modelo, o administrativo predomina sobre o pastoral; a sacramentalização sobre a evangelização; a quantidade ou o número dos adeptos sobre a qualidade; o pároco sobre o bispo; o padre sobre o leigo; o rural sobre o urbano; o pré-moderno sobre o moderno; a massa sobre a comunidade.

Para a superação da "pastoral de conservação", Aparecida propóe uma "pastoral decididamente missionária”, que rompa com uma "Igreja auto-referencial”, ao colocarse "em saída" para as periferias, sem a tentação de "domesticar as fronteiras" ${ }^{61}$. O

\footnotetext{
${ }^{56}$ Celam, Documento de Aparecida. Quinta Conferência Geral dos Bispos da América Latina e Caribe 100h.

${ }^{57}$ Ibid. $100 \mathrm{~b}$.

${ }^{58}$ Ibíd. 370.

${ }^{59}$ Celam, Documento de Medellín. Segunda Conferência Geral dos Bispos da América Latina e Caribe 6,1.

${ }^{60}$ Azzi, Memórias eclesiásticas. Documentos comentados, 4.

${ }^{61}$ Vian, Em busca de uma Igreja do amor. O Papa Francisco responde, 186.
} 
Instrumentum laboris do Sínodo da Amazônia frisa a urgente necessidade de "deixar para trás uma tradição colonial monocultural, clericalista e impositiva”" ${ }^{2}$.

Trata-se de uma postura alicerçada na eclesiologia do Vaticano II, segundo a qual não se pode conceber a evangelização fora do trinômio Igreja-Reino-mundo, condição para superar o eclesiocentrismo e testemunhar "os valores do Reino no âmbito da vida social, econômica, política e cultural" ${ }^{63} \mathrm{e}$, assim, transformar a "cidade atual" na "Cidade Santa" ${ }^{64}$

A comunidade dos discípulos de Jesus, que é a Igreja, não se identifica com o Reino de Deus; ela é seu sacramento histórico-salvífico. O Reino não acontece somente na Igreja, como comunidade socialmente constituída dos redimidos. Como também não acontece somente na interioridade secreta da consciência, na meta-histórica subjetividade religiosa, mas se produz na concretude da realização do amor ao próximo, apesar da ambiguidade da história, em suas objetivaçôes empiricamente perceptíveis.

Uma Igreja com rosto próprio na Amazônia, só pode ser plasmado pela autoconsciência de cristáos que se veem peregrinos na história, companheiros de caminho com toda a humanidade, buscando tornar presente o Reino de Deus no contexto amazônico. Trata-se de, a partir eclesiologia do Vaticano II, recebida por Medellín, situar o ser a missão da Igreja neste contexto, de características, exigências e desafios próprios. Como para Medellín as "CEBs são a célula inicial da estruturação eclesial" a Igreja, no seio da Igreja local, é configurada em pequenas comunidades inseridas profeticamente na sociedade, toda ela ministerial e sujeito da evangelização.

O Instrumentum laboris do Sínodo da Amazônia ressalta que na regiáo, "seus pastores formaram pequenas comunidades de rosto humano, onde as pessoas se sentem valorizadas pessoalmente" ${ }^{\prime 6}$. É a sinodalidade vivida e exercida no princípio da subsidiariedade, em que o poder se faz serviço dos níveis eclesiais superiores aos inferiores ${ }^{67}$.

\footnotetext{
${ }^{62}$ Sínodo dos Bispos-Secretaria Geral, Amazônia: novos caminhos para a Igreja e para uma ecologia integral. Instrumentum laboris 118.

${ }^{63}$ Celam, Documento de Aparecida. Quinta Conferência Geral dos Bispos da América Latina e Caribe 212. ${ }^{64}$ Ibíd. 516.

${ }^{65}$ Celam, Documento de Medellín. Segunda Conferência Geral dos Bispos da América Latina e Caribe 6,1.

${ }^{66}$ Sínodo dos Bispos-Secretaria Geral, Amazônia: novos caminhos para a Igreja e para uma ecologia integral. Instrumentum laboris 138.

${ }^{67}$ Amerindia, Hacia el Sinodo Panamazónico. Desafíos y aportes desde América Latina y el Caribe, 67-77.
} 


\section{A conversão no âmbito da ação pastoral}

Em segundo lugar, conversão pastoral é essencialmente mudança no âmbito das práticas ou da ação da Igreja. Para Aparecida, é preciso uma ação evangelizadora que chegue às pessoas, para além de comunidades massivas, constituídas de cristãos não evangelizados, de débil identidade cristã e pouca pertença eclesial ${ }^{68}$. A própria natureza do cristianismo consiste em reconhecer a presencia de Jesus Cristo e segui-lo ${ }^{69}$. Evangelizar não consiste simplesmente em incorporar pessoas a uma instituição, mas antes de tudo encarnar o Evangelho na vida de pessoas contextualizadas.

Mas, não se trata também de um evangelho supostamente fora da contingência da história e das culturas, o que não passaria da transmissão de uma determinada versão dele, levando a uma Igreja monocultural. A Igreja é consequência da adesão a Jesus Cristo e seu Reino. Não há cristão sem Igreja. Portanto, "evangelizar é inculturar o Evangelho" 70 , por um processo, no qual, o sujeito é quem recebe a mensagem, incorporando-a, segundo sua cultura, em sua vida e em suas relaçóes.

E como evangelizar não consiste simplesmente em incorporar pessoas a uma instituição, mas encarnar o Evangelho na vida de pessoas contextualizadas, a ação da Igreja precisa "engendrar padróes culturais alternativos para a sociedade atual" A promoção da vida plena em Cristo nos leva a assumir, evangelicamente, as tarefas prioritárias que contribuem com a dignificaçáo de todos os seres humanos ${ }^{72}$.

Por isso, é preciso trabalhar junto com demais pessoas e instituiçóes ${ }^{73}$, fazendo dos pobres sujeitos de mudança e de transformação de sua situaçãa ${ }^{74}$, evitando o paternalismo ${ }^{75}$, no diálogo com as ciências ${ }^{76}$, cuidando da ecologia ${ }^{77}$, inculturando o Evangelho $o^{78}$, de modo particular no mundo urbano $^{79} \mathrm{e}$ na vida pública ${ }^{80}$.

${ }^{68}$ Celam, Documento de Aparecida. Quinta Conferência Geral dos Bispos da América Latina e Caribe 226a.

${ }^{69}$ Ibíd. 244.

${ }^{70}$ Ibíd. 491.

${ }^{71}$ Ibid. 480.

72 Sínodo de los Obispos-Secretaría, "Amazonía: nuevos caminos para la Iglesia y para una ecología integral", 7.

${ }^{73}$ Celam, Documento de Aparecida. Quinta Conferência Geral dos Bispos da América Latina e Caribe 384.

${ }^{74}$ Ibid. 394.

${ }^{75}$ Ibid. 397.

${ }^{76}$ Ibid. 465.

77 Ibid. 474.

${ }^{78}$ Ibid. 479.

${ }^{79}$ Ibid. 501.

${ }^{80}$ Ibid. 509. 
Consequentemente, a Igreja está "convocada a ser advogada da justiça e defensora dos pobres", diante das intoleráveis desigualdades sociais e econômicas, que clamam ao céu ${ }^{81}$. A opção pelos pobres, "para que seja preferencial, precisa transpassar todas as nossas estruturas e prioridades pastorais" esforços para fortalecer uma pastoral social estruturada, orgânica e integral, que com a assistência e a promoção humana, se faça presente nas novas realidades de exclusão e marginalização, lá onde a vida está mais ameaçada" ${ }^{33}$.

O Instrumentum laboris do Sínodo da Amazônia frisa que "a opção pelos pobres é o critério para analisar os projetos de construção da sociedade" ${ }^{84}$. Para isso, é preciso "favorecer a formação de um laicato capaz de atuar como verdadeiro sujeito eclesial e competente interlocutor entre a Igreja e a sociedade" ${ }^{85}$.

A conversão da Igreja no âmbito das açóes no contexto amazônico, dado que a maioria da população vive nas cidades, passa também por uma pastoral urbana ${ }^{86}$. Aparecida recomenda:

- Desenvolver "um estilo de ação adequado à realidade urbana, em sua linguagem, estruturas, práticas e horários".

- Agir apoiado em um plano pastoral "orgânico e articulado, que incida sobre o conjunto da cidade", com estratégias para chegar aos "condomínios fechados, edifícios residenciais e favelas".

- Ter uma maior presença nos "centros de decisão da cidade, tanto nas estruturas administrativas como nas organizaçôes comunitárias" ${ }^{\text {87 }}$.

Trata-se de uma pastoral urbana que: atenda as variadas e complexas categorias sociais, econômicas, políticas e culturais, compostas de elites, classe média e pobres; transforme as paróquias cada vez mais em comunidades de comunidades; aposte na experiência de comunidades ambientais, integradas em comunidades em nível supraparoquial e diocesano; fomente a pastoral da acolhida aos que chegam à cidade e aos

\footnotetext{
${ }^{81}$ Ibid. 395.

${ }^{82}$ Ibid. 396.

${ }^{83}$ Ibid. 401.

${ }^{84}$ Sínodo dos Bispos-Secretaria Geral, Amazônia: novos caminhos para a Igreja e para uma ecologia integral. Instrumentum laboris 109.

${ }^{85}$ Celam, Documento de Aparecida. Quinta Conferência Geral dos Bispos da América Latina e Caribe 497.

${ }^{86}$ Ver: Antoniazzi. "Princípios teológico-pastorais para a presença da Igreja na cidade; Libânio, "As lógicas da cidade. O impacto sobre a fé e sob o impacto da fé".

${ }^{87}$ Celam, Documento de Aparecida. Quinta Conferência Geral dos Bispos da América Latina e Caribe 518.
} 
que já vivem nela; intensifique a presença eclesial nas periferias urbanas, que crescem devido às migrações internas e situaçóes de exclusão $0^{88}$.

\section{A conversão nas relações de igualdade e autoridade}

Em terceiro lugar, conversão pastoral implica mudanças nas relaçôes de igualdade e autoridade. Neste particular, para Aparecida, o clericalismo, o autoritarismo, a minoridade do laicato, a discriminação das mulheres e a falta de corresponsabilidade entre todos os batizados na Igreja, são os grandes obstáculos para levar adiante a renovação proposta pelo Vaticano II. Daí a necessidade, na obra da evangelização, de duas mudanças básicas:

- Passar do binômio clero-leigos a comunidade-ministérios. Para o Vaticano II não existe duas classes de cristãos - clero-leigos - mas, um único gênero, os batizados, que engendra outro binômio: comunidade-ministérios ${ }^{89}$. Por isso, Aparecida, com Puebla, fala da Igreja como "comunhão e participaçáo" 90 , "casa e escola de comunhão" ". Daí a necessidade, na obra da evangelizaçáo, da participação "dos leigos no discernimento, tomada de decisōes, do planejamento e da execuçáo"92. O Instrumentum laboris do Sínodo da Amazônia fala da necessidade de "superar toda forma de clericalismo para viver a fraternidade e o serviço como valores evangélicos, que animam a relação entre a autoridade e os membros da comunidade" ${ }^{{ }_{3}}$.

- A co-responsabilidade dos batizados, em uma Igreja toda ela ministerial. Segundo o Vaticano II, todo o povo de Deus é um povo profético, sacerdotal e régio, que tem o batismo como fundamento de todos os demais ministérios. Por isso, urgem processos de tomada de decisóes relativas à pastoral, que contemplem a participação de todos, na co-responsabilidade de todos os batizados na obra da evangelizaçăo $0^{94}$. Neste sentido, destaca Aparecida a necessidade de promover "o protagonismo dos leigos, em especial das mulheres", estas com

${ }^{88}$ Ibid. 517.

${ }^{89}$ Schickendantz, “A definição tipológica do leigo cristão, conforme o Vaticano II", 981-1000.

${ }^{90}$ Celam, Documento de Aparecida. Quinta Conferência Geral dos Bispos da América Latina e Caribe 213. ${ }^{91}$ Ibid. 158.

${ }^{92}$ Ibíd. 371. Ver: Ascenjo Gálvez. "La conversión pastoral: un llamado a vivir en libertad y comunión”, 270.

${ }^{93}$ Sínodo dos Bispos-Secretaria Geral, Amazônia: novos caminhos para a Igreja e para uma ecologia integral. Instrumentum laboris $119 \mathrm{c}$.

${ }^{94}$ Ver: Schickendantz, El ministerio eclesial. Responsables en la comunidad cristiana. 
ministérios e "efetiva presencia nas esferas de planejamento e nos processos tomada de decisáo" 95 .

É necessário, na América Latina, superar uma mentalidade machista, que ignora a novidade do cristianismo, que reconhece e proclama a "igual dignidade e responsabilidade da mulher em relaçáo ao homem" ${ }^{96}$. O Instrumentum laboris do Sínodo da Amazônia chama a atenção que

...as culturas amazônicas possuem um alto sentido de comunidade, igualdade e de solidariedade, por isso não aceita o clericalismo; os povos originários possuem uma rica tradiçáo de organização social onde a autoridade é rotativa e com um profundo sentido de serviço. ${ }^{97}$

Para uma Igreja comunhão e sinodal na Amazônia, apresenta-se o imperativo da formação de um laicato adulto na fé, no seio de uma Igreja toda ela ministerial, na qual quem preside ou coordena não comanda, mas está a serviço, em uma relação horizontal. A sinodalidade se assenta sobre o sensus fedelium, no seio do qual, se situam todos os batizados, incluídos os ministros ordenados.

\section{A conversão no âmbito das estruturas}

Em quarto lugar, a conversão pastoral precisa descer ao nível das estruturas ${ }^{98}$. Estas são um elemento fundamental da visibilidade da Igreja, pois, afetam seu caráter de sacramento. As estruturas são também mensagem ${ }^{99}$.

Para Aparecida, as estruturas sociais injustas da sociedade desafiam as estruturas da Igreja, pois elas não conseguem responder às necessidades dos necessitados. Por isso, a opçáo pelos pobres, enquanto opção preferencial, precisa "atravessar todas as nossas estruturas e prioridades pastorais" ${ }^{100}$. A Igreja, como "casa dos pobres" 101 , "Igreja

${ }^{95}$ Celam, Documento de Aparecida. Quinta Conferência Geral dos Bispos da América Latina e Caribe 458.

96 Ibid. 453.

${ }^{9}$ Sínodo dos Bispos-Secretaria Geral, Amazônia: novos caminhos para a Igreja e para uma ecologia integral. Instrumentum laboris 127.

98 Ver: Fernandes, Conversión pastoral y nuevas estructuras. ¿Lo tomamos en serio? Schickendantz, Cambioesructural de la Iglesia como tarea y oportunidad, 28-29.

99 Duquoc, “Creo en la Iglesia”. Precariedad institucional y Reino de Dios, 125129.

${ }^{100}$ Celam, Documento de Aparecida. Quinta Conferência Geral dos Bispos da América Latina e Caribe 396.

${ }^{101}$ Ibid. 8. 
samaritana"102, deve criar estruturas abertas para acolher a todos ${ }^{103}$, em perspectiva da vida em abundância ${ }^{104}$.

Isso implica uma pastoral transformadora, capaz de assumir com nova força a opção pelos pobres, sem a qual não é possível uma ordem justa na sociedade ${ }^{105}$. Cabe, pois, "promover renovados esforços para fortalecer uma pastoral social estruturada, orgânica e integral, que com a assistência e a promoção humana, se faça presente nas novas realidades de exclusão e marginalização, lá onde a vida está mais ameaçada" ${ }^{106}$.

No âmbito da conversão das estruturas, para Aparecida, expressão de uma Igreja que quer assumir com mais força a opção pelos pobres são as pequenas comunidades eclesiais ou de base ${ }^{107}$, para Medellín, "célula inicial de estruturação eclesial e foco de evangelização". Elas permitem o povo chegar a um conhecimento maior da Palavra de Deus, ao compromisso social em nome do Evangelho, ao surgimento de novos serviços leigos e à educação da fé dos adultos ${ }^{108}$. Estas pequenas comunidades proféticas, tendo "a Palavra de Deus como fonte de sua espiritualidade",

...demonstram seu compromisso evangelizador e missionário entre os mais simples e distantes e são expressão visível da opçáo preferencial pelos pobres. São fonte e semente de variados serviços e ministérios, a favor da vida, na sociedade e na Igreja. ${ }^{109}$

Isso implica renovar a paróquia ${ }^{110}$, sem dúvida célula viva da Igreja, mas que necessita uma vigorosa renovação, para que seja: espaço de iniciação cristã; lugar de educação e celebração da fé, aberta à diversidade dos carismas, serviços e ministérios; organizada de maneira comunitária e responsável; integradora dos movimentos; aberta à diversidade cultural e a projetos pastorais supra-paroquiais e das realidades circundantes $^{111}$. Por isso, recomenda Aparecida, levando em consideração suas dimensões, é aconselhável sua

${ }^{102}$ Ibid. 26.

${ }^{103}$ Ibid. 412.

${ }^{104}$ Ibid. 121.

105 Ibid. 399.

${ }^{106}$ Ibid. 401.

${ }^{107}$ Oliveros, "Igreja particular, paróquia e CEBs em Aparecida”, 138-145.

${ }^{108}$ Celam, Documento de Aparecida. Quinta Conferência Geral dos Bispos da América Latina e Caribe 178.

${ }^{109}$ Ibid. 179.

${ }^{110}$ Libânio, "Conversão pastoral e estruturas eclesiais", 323.

${ }^{111}$ Celam, Documento de Aparecida. Quinta Conferência Geral dos Bispos da América Latina e Caribe 170. 
...setorização em unidades territoriais menores, com equipes de animação e coordenação que permitam uma maior proximidade às pessoas e grupos que vivem na regiāo". Dentro destes setores, é aconselhável também, "a criação de grupos de famílias, que ponham em comum sua fé e as respostas a seus próprios problemas. ${ }^{112}$

Para uma Igreja com rosto próprio na região amazônica, a renovação das estruturas adquire relevância no que diz respeito ao modo de relaçáo entre as igrejas locais e destas com a Igreja de Roma. A autonomia das igrejas locais implica uma reforma do Primado, em especial da cúria romana, projeto já em curso, levado a cabo pelo papa Francisco. Esta "sã descentralização" leva igualmente a repensar o papel das conferências episcopais, seu estatuto teológico, seu papel magisterial e sua competência também no campo jurídico e disciplinar. Neste particular, o Instrumentum laboris frisa que para a consolidação de uma Igreja autóctone na Amazônia há a necessidade, também, da criação de um organismo colegial dos bispos da região, que assegure organicidade e efetividade na ação evangelizadora em seu contexto ${ }^{113}$.

\section{Considerações finais}

Para uma evangelização consequente com o contexto amazônico, as igrejas locais da regiâo precisam fazer de seu Sínodo um passo importante na configuração de igrejas autóctones, expressão de uma eclesiologia pluriforme, conforme o modelo neotestamentário. É a hora de ousar, pois apesar da abertura do novo pontificado, juridicamente, continua a milenar centralização que impede responder com mais agilidade e propriedade aos desafios oriundos de um contexto muito particular. Fundado na legitimidade do exercício da sinodalidade eclesial entre as igrejas locais e a Igreja de Roma, o Sínodo precisa ser expressão da autonomia necessária para tomar decisóes diante de certas demandas do contexto amazônico que náo podem esperar.

Sem a necessária autonomia, um rosto próprio de Igreja, fruto da inculturação da fé no contexto amazônico segundo o perfil da tradiçâao eclesial libertadora tecida em torno a Medellín, continuará mais desejo do que realidade ou entâo "brasas sob cinzas" de um largo processo de involução eclesial. É hora de passar da resistência à ousadia de avançar, da repetiçáo de modelos de Igreja esclerosados à criatividade, sob o dinamismo do Espírito. Tarefas concretas como uma liturgia que incorpore no

\footnotetext{
112 Ibid. 372.

113 Sínodo dos Bispos-Secretaria Geral, Amazônia: novos caminhos para a Igreja e para uma ecologia integral. Instrumentum laboris $128 \mathrm{f}$.
} 
rito a cultura dos povos da região amazônica ${ }^{114}$, uma teologia própria como a teologia índia e a ecoteologia, ministérios configurados segundo as condiçóes e necessidades locais, enfim, uma pastoral de conversão missionaria que faça das periferias o centro da Igreja, precisam fazer parte da agenda do Sínodo.

Por isso, como diz Aparecida, só a conversão pastoral da Igreja como um todo pode levar a retomar a renovação do Vaticano II e a tradição eclesial libertadora da Igreja na América Latina no novo contexto em que vivemos, de onde brota a necessidade de uma Igreja com rosto amazônico. É uma tarefa imensa e complexa, pois implica conversão na auto-consciência da Igreja, nas açóes, nas relaçóes de autoridade e nas estruturas, sob o protagonismo do Espírito. Tarefa grande, mas não impossível se a Igreja conseguir "desinstalar-se de seu comodismo, estancamento e tibieza, à margem do sofrimento dos pobres do continente". Por isso, dizem os bispos em Aparecida, "esperamos um novo Pentecostes que nos liberte do cansaço, da desilusão e da acomodação em que nos encontramos" ${ }^{115}$.

\section{Referências bibliográficas}

Alberigo, Giuseppe. "O Vaticano II e sua história”. Concilium 312/4 (2005): 7-19.

Amerindia. Hacia el Sinodo Panamazónico. Desafíos y aportes desde América Latina y el Caribe. Bogotá: DGP Editores, 2019.

Antoniazzi, A. "Princípios teológico-pastorais para a presença da Igreja na cidade".

Em A presença da Igreja na cidade, editado por Instituto Nacional de Pastoral. Petrópolis : Vozes, 1994.

Aparecido da Silva, Antonio. "Théologie afro-américaine au Brésil: expression du pluralisme théologique”. Em Risquer la foi dans nos sociétés. Églises d'Amérique latine et d'Europe en dialogue, dirigido por Hadwig Ana Maria Muller e Denis Villepelet, 183-197. Paris: Karthala, 2005.

Ascenjo Gálvez, L. A. "La conversión pastoral: un llamado a vivir en libertad y comunión”. Medellín 134 (2008): 247-275.

Azzi, Riolando. Memórias eclesiásticas. Documentos comentados. Rio de Janeiro: UFRJ, 2001.

${ }^{114}$ Ferreira, "Uma Igreja com rosto amazônico", 28-29.

${ }^{115}$ Celam, Documento de Aparecida. Quinta Conferência Geral dos Bispos da América Latina e Caribe 362. 
Bento XVI. "Discurso inaugural”. Em Documento de Aparecida. Quinta Conferência Geral dos Bispos da América Latina e Caribe, Celam, 267-284. São Paulo: Paulus-Paulinas, 2007.

Beozzo, José Oscar. "Globalisation en Amérique latine dans le contexte historique des interactions mondiales". Em Risquer la foi dans nos sociétés. Églises d'Amérique latine et d'Europe en dialogue, dirigido por Hadwig Ana Maria Muller e Denis Villepelet, 85-116. Paris: Karthala, 2005.

Brighenti, Agenor. "A pastoral na vida da Igreja. Repensando a missão evangelizadora em tempos de mudança". Em CNBB-Comissão Episcopal para a Animação Bíblico-catequética. Congresso Nacional de Catequese, 117-138. Brasília: Ed. CNBB: 2012.

. Dívida externa e neocolonialismo: por uma globalização da solidariedade. São Paulo: Paulinas, 2000.

. "Énfasis pastorales de la Iglesia en América Latina y el Caribe en los últimos 50 ańos”. Medellín 123 (2005): 375-398.

. Por uma evangelização inculturada. Princípios pedagógicos e passos metodológicos. São Paulo: Paulinas, 1998.

Cadavid, Luis Álvaro. "El camino pastoral de la Iglesia en América Latina y el Caribe”. Medellin 123 (2005): 331-374.

Cartaxo Rolim, Francisco. "Neoconservadorismo eclesiástico e uma estratégia política”. REB 49 (1989): 259-281.

Celam. Documento de Aparecida. Quinta Conferência Geral dos Bispos da América Latina e Caribe. São Paulo: Paulus-Paulinas, 2007.

- Documento de Medellin. Segunda Conferência Geral dos Bispos da América Latina e Caribe. Petrópolis: Vozes, 1968.

- Documento de Santo Domingo. Quarta Conferência Geral dos Bispos da América Latina e Caribe. Santo Domingo, 1992. Petrópolis: Vozes, 1992.

. "A eclesiologia de Aparecida". Em Tejiendo redes de vida y esperanza. Cristianismo, sociedad y profecía en América Latina y El Caribe, organizado por Amerindia, 138-145. Bogotá: Indo-American Press, 2006.

Comblin, J. “Aporias da inculturação (1)”. REB 56/223 (1996): 664-684.

. "Aporias da inculturação (2)". REB 56/224 (1996): 903-929.

. "Inculturação e libertação". Convergência 235 (1990): 423-432. 
Concílio Vaticano II. "Decreto Ad gentes sobre a atividade missionária da Igreja (1965)". Vatican, http://www.vatican.va/archive/hist councils/ii vatican council/documents/vat-ii_decree_19651207_ad-gentes_po.html (acessado em 25 de março de 2019).

De Aquino, Tomas. Suma teológica. São Paulo: Loyola, 2001.

De França Miranda, Mario. Inculturação da fé. Uma abordagem teológica. São Paulo: Loyola, 2001.

Duquoc, C. "Creo en la Iglesia". Precariedad institucional y Reino de Dios. Col. Presencia Teológica 112. Santander: Sal Térrea, 2001.

Espeja Pardo, J. "La conversión pastoral como cambio de paradigmas, métodos y lenguajes". Medellin 134 (2008): 277-308.

Esquerda Bifet, Juan. Teología de la evangelización. Curso de misionología. Madrid: Biblioteca de Autores Cristianos, 1995.

Fernandes, Víctor Manuel. Conversión pastoral y nuevas estructuras. ¿Lo tomamos en serio? Buenos Aires: Ágape Libros, 2010.

Ferreira, Reuberson. "Uma Igreja com rosto amazônico". Vida pastoral 327 (2019): 23-34.

Floristán, Casiano. "Evangelización". Em Nuevo dicionario de pastoral, dirigido por C. Floristán, 550-559. Madrid: San Pablo, 2002.

Francisco. Exortaçâo apostólica Evangelii gaudium. Roma: Libreria Editrice Vaticana, 2013.

González Faus, José Ignacio. "El meollo de la involución eclesial". Razón y fe 220, nn.1089/90 (1989): 67-84.

Gutiérrez, Gustavo. "La recepción del Vaticano II en América Latina”. Em La recepción del Vaticano II, editado por G. Alberigo y J.-P. Jossua, 213-237. Madrid: Cristiandad, 1987.

Huenermann, Peter. "Silêncio frente ao Concílio Vaticano II?" Concilium 346/3 (2012): 283-296.

Keller, Miguel Ángel. "A Conferência de Puebla: contexto, preparação, realização, conclusôes, recepção". Em Compêndio das Conferências dos Bispos da América Latina e Caribe, organizado por Agenor Brighenti e João Décio dos Passos, 83-93. São Paulo: Paulinas-Paulus, 2017. 
. "El proceso evangelizador de la Iglesia en América Latina. De Río a Santo Domingo". Medellin 81 (1995): 5-43.

Ladrière, Paul, e Rene Luneau. Le retour des certitudes. Paris: Le Centurion, 1988. Legrand, Hervé. "La réalisation de l'Église en un lieu”. Em Initiation à la pratique de la théologie. Vol. III. Dogmatique 2, editado por B. Lauret et F. Refoulé, 143-345. Paris: Cerf, 1993.

Lévinas, E. Ethique et infni. Paris: Fayard, 1982. . Totalidad e infinito. Salamanca: Sígueme, 1987.

Libânio, João Batista. A volta à grande disciplina. São Paulo: Loyola, 1984. - As lógicas da cidade. O impacto sobre a fé e sob o impacto da fé. Sáo Paulo: Loyola, 2001.

. “Conversão pastoral e estruturas eclesiais". Medellín 134 (2008): 309-329.

Lima Vaz, Henrique Claudio de. "Igreja-reflexo vs Igreja-fonte". Cadernos Brasileiros 46 (1968): 17-22.

Lobinger, Fritz. Padres para amanhã: proposta para comunidades sem eucaristia. São Paulo: Paulus, 2007.

López H., Eleazar. "La teología índia en la globalización actual”. Em $O$ mar se abriu. Trinta anos de teologia na América Latina, coordenado por L. C. Susin, 109-130. São Paulo: Soter/Loyola: 2000.

Luneau, Rene, e Paul Ladrière. Le rêve de Compostelle. Paris: Centurion, 1990.

Mardones, José María. Postmodernidad y neoconservadurismo. Reflexiones sobre la fe y la cultura. Estella (Navarra): Verbo Divino, 1991.

Melloni, Alberto. "O que foi o Vaticano II? Breve guia para os juízos sobre o Concílio”. Concilium 312/4 (2005) 34-59.

Oliveros, R. "Igreja particular, paróquia e CEBs em Aparecida”. Em V Conferência de Aparecida. Renascer de uma esperança, organizado por Amerindia, 183-193. São Paulo: Paulinas, 2007.

Paloschi, Roque. "O Sínodo da Amazônia: grito à consciência, memória da missão, opção pela vida”. Vida pastoral 327 (2019): 15-22.

Ramos, Julio A. Teología pastoral. Madrid: Biblioteca de Autores Cristianos, 2001. 
Ratzinger, Joseph, e Vittorio Messori. Informe sobre la fe. Madrid: Biblioteca de Autores Cristianos, 1985.

Ricoeur, P. Soi-même comme un autre. Paris: Seuil, 1990.

Roca Alcazar, Fernando. "El Sínodo amazónico, la Amazonía y la Iglesia”. Perspect. Teol., Vol. 51/1 (2019): 55-67.

Scatena, Silvia. In populo pauperum. La chiesa latinoamericana dal Concilio a Medellin (1962-1968). Bologna: Il Molino, 2007.

Schickendantz, Carlos. "A definiçâo tipológica do leigo cristão, conforme o Vaticano II". Em A Igreja do Concílio Vaticano II, organizado por G. Baraúna, 981-1000. Petrópolis: Vozes, 1965.

. Cambio estructural de la Iglesia como tarea y oportunidad. Córdoba: EDUCC, 2005.

. El ministerio eclesial. Responsables en la comunidad cristiana. Madrid: Cristiandad, 1983.

Sínodo de los Obispos-Secretaría. "Amazonía: nuevos caminos para la Iglesia y para una ecología integral". Boletín Oficina de Prensa de la Santa Sede, El Vaticano, 8 de junio de 2018.

Sínodo dos Bispos-Secretaria Geral. Amazônia: novos caminhos para a Igreja e para uma ecologia integral. Instrumentum laboris. Roma: Librería Editrice Vaticana, 2019.

Sobrino, Jon. "El Vaticano II y la Iglesia latinoamericana". Em El Vaticano II, veinte años después, editado por C. Floristán y J.-J. Tamayo, 105-134. Madrid: Cristiandad, 1985.

Suess, Paulo (org.). "A proposta do Papa Francisco para o Sínodo Pan-amazônico de 2019: sinodalidade, missão, ecologia integral”. Perspect. Teol. 51/1 (2019): $15-30$.

. Culturas e evangelização. A unidade da razão evangélica na multiplicidade de suas vozes: pressupostos, desafios e compromissos. São Paulo: Loyola, 1991.

. Evangelizar a partir dos projetos históricos dos outros. Ensaio de missiologia.

São Paulo: Paulus, I995.

. "Inculturação: desafios, caminhos, metas". REB 49/193 (1989): 81-126.

. "No Verbo que se fez carne, o Evangelho se faz cultura". REB 54/213 (1994): 36-49. 
Theobald, Christoph. "As opções teológicas do Concílio Vaticano II: em busca de um princípio 'interno’ de interpretação”. Concilium 312/4 (2005): 115-138.

Tillard, Jean Marie R. Église d'Églises. L'écclesiologie de communion. Paris: Du Cerf, 1987.

Vian, Giovani Maria. Em busca de uma Igreja do amor. O Papa Francisco responde. Petrópolis: Vozes, 2015.

Wolff, Elias. "A exigência do diálogo inter-religioso no Sínodo para a Amazônia 2019”. Perspect. Teol. 51/1 (2019): 69-93. 